\title{
CURRENT AND PAST ADHERENCE TO THE WORLD CANCER RESEARCH FUND/AMERICAN INSTITUTE FOR CANCER RESEARCH RECOMMENDATIONS IN SURVIVORS OF BREAST CANCER
}

\author{
Emilia Katędkiewicz' ${ }^{1}$ Dorota Szostak-Wegierek ${ }^{l}$ \\ ${ }^{1}$ Medical University of Warsaw, Faculty of Health Science, Department of Clinical Dietetics, \\ Erazma Ciołka 27, 01-445 Warsaw, Poland
}

\begin{abstract}
Background: Breast cancer is the first in the structure of the incidence of neoplastic diseases in women, with the number of affected individuals becoming higher every year. The risk of breast cancer is influenced not only by genetic factors, but also by the lifestyle. Proper dietary habits, a high level of physical activity and normal body weight not only reduce the risk of developing a primary neoplastic lesion, but also a recurrence. In 2007 the World Cancer Research Fund (WCRF) and American Institute for Cancer Research (AICR) published their recommendations concerning lifestyle in the prophylaxis of neoplasms.

Objective. The aim of the study was to assess whether the adherence to WCRF/AICR recommendations influenced the risk of developing breast cancer in women.

Materials and methods: A case control study included 108 women aged over 50 with a history of breast cancer. The study group was divided into two subgroups: women who completed oncological treatment and experienced no recurrences for at least 5 years (group I, $\mathrm{n}=82$ ) and women who had a recurrence (group II, $\mathrm{n}=26$ ). The control group included women with no history of breast cancer $(\mathrm{n}=74)$. The adherence of lifestyle was assessed by assigning points for $8 \mathrm{WCRF} / \mathrm{AICR}$ recommendations. The results were compared in the study and control groups, both in all participants and separately in those who declared no changes in dietary habits after being diagnosed with breast cancer.

Results. The adherence of lifestyle to WCRF/AICR recommendations was significantly lower in the group of women with a history of cancer compared to the control group. It was reported both in the study group as a whole (5.5 \pm 1.34 vs $6.4 \pm$ 1.48 points) and in those who declared no changes in dietary habits after being diagnosed with breast cancer $(5.3 \pm 1.24$ vs $6.6 \pm 1.38$ points). The differences in the lifestyles of the participants with breast cancer and those in the control group were associated predominantly with the adherence to recommendations concerning appropriate physical activity, avoiding the consumption of sweetened drinks and limiting the consumption of processed and red meat.

Conclusions. The results of the study confirmed the benefits of complying with WCRF/AICR recommendations in the prevention of breast cancer.
\end{abstract}

Key words: breast cancer, dietary habits, lifestyle, recurrence

\section{STRESZCZENIE}

Wprowadzenie. Nowotwór piersi zajmuje pierwsze miejsce w strukturze zachorowań na nowotwory u kobiet, a z roku na rok liczba chorujących kobiet rośnie. Na ryzyko raka piersi wpływ mają nie tylko czynniki genetyczne, ale także styl życia. Prawidłowy sposób odżywiania, wysoki poziom aktywności fizycznej i utrzymywanie prawidłowej masy ciała zmniejszają ryzyko nie tylko pojawienia się pierwotnej zmiany nowotworowej, ale także wznowy. W roku 2007 Światowy Fundusz Badań nad Rakiem (WCRF) oraz Amerykański Instytut Badań nad Rakiem (AICR) wydały zalecenia dotyczące stylu życia w profilaktyce nowotworów.

Cel. Celem badań była ocena czy stosowanie zaleceń WCRF/AICR ma wpływ na ryzyko powstania raka piersi u kobiet. Material i metody. Badanie kliniczno-kontrolne objęło 108 kobiet po 50. roku życia z rakiem sutka w wywiadzie. Badane podzielono na dwie grupy: kobiety, które zakończyły leczenie onkologiczne oraz pozostawały bez wznowy przez minimum

Corresponding author: Emilia Kałędkiewicz, Warszawski Uniwersytet Medyczny, Wydział Nauki o Zdrowiu, Zakład Dietetyki Klinicznej, ul. Erazma Ciołka 27, 01-445 Warszawa, tel. +48 606202 953, e-mail: emilia.kaledkiewicz@wum.edu.pl

(C) Copyright by the National Institute of Public Health - National Institute of Hygiene 
5 lat (grupa I, n=82) i kobiety, u których wystąpiła wznowa choroby (grupa II, n=26). Grupę kontrolną stanowiły kobiety, u których nigdy nie rozpoznano raka piersi $(\mathrm{n}=74)$. Metodą punktową oceniono zgodność stylu życia z 8 zaleceniami WCRF/AICR. Porównano uzyskaną punktację w grupie badanej i kontrolnej, zarówno u wszystkich uczestniczek, jak i osobno u tych, które deklarowały brak zmiany sposobu żywienia po zachorowaniu na raka piersi.

Wyniki. Kobiety z historią nowotworową cechowały się istotnie mniejszą zgodnością stylu życia z zaleceniami WCRF/AICR w porównaniu z grupą kontrolną. Dotyczyło to zarówno całej grupy badanych kobiet $(5,5 \pm 1,34$ vs $6,4 \pm 1,48$ punktów), jak i tych które deklarowały brak zmian sposobu żywienia po zachorowaniu na raka piersi (5,3 $\pm 1,24$ vs $6,6 \pm 1,38$ punktów). Różnice w stylu życia między uczestniczkami z rakiem piersi w wywiadzie w porównaniu z grupą kontrolną dotyczyły przede wszystkim przestrzegania zalecenia dotyczącego odpowiedniej aktywności fizycznej, unikania spożycia słodzonych napojów, a także ograniczenia spożycia przetworzonego i czerwonego mięsa.

Wnioski. Wyniki badania potwierdziły korzyści płynące z przestrzegania zaleceń WCRF/AICR w zapobieganiu rakowi piersi.

Słowa kluczowe: rak piersi, sposób żywienia, styl życia, wznowa

\section{INTRODUCTION}

Statistics concerning the incidence of breast cancer are disturbing. This type of cancer is the first in the structure of the incidence of neoplastic diseases in women, with the number of affected individuals becoming higher every year [27]. The risk of breast cancer is influenced not only by genetic factors, but also by the lifestyle. Proper dietary habits, a high level of physical activity and normal body weight not only reduce the risk of developing a primary neoplastic lesion, but also a recurrence [21]. The list of recommendations concerning lifestyle published by WCRF/AICR aims at promoting the primary neoplasm prophylaxis and diminishing the risk of recurrence. The recommendations tackle the issues of maintaining normal body weight, regular physical activity, avoiding the consumption of food promoting body weight gain, increasing the consumption of foods of plant origin, while reducing the consumption of foods of animal origin, limiting the consumption of alcoholic drinks, salty foods, avoiding dietary supplements in the prophylaxis of neoplastic diseases, and also breastfeeding [28].

The aim of the study was to assess the influence of complying with WCFR/AIRC recommendations on the risk of breast cancer and its recurrence.

\section{MATERIAL AND METHODS}

The case-control study was conducted in Warsaw and its vicinity in the years 2013-2016. The study included 182 women aged over 50, divided into 108 women in the study group and 74 in the control group. The study group was then divided into two subgroups: women who completed breast cancer treatment without a recurrence for at least 5 years (group $\mathrm{I}, \mathrm{n}=82$ ), and women with a history of recurrence (group II, $\mathrm{n}=26$ ). The study group included the patients of the Holy Family Specialist Hospital (Independent Public Health Care Centre), MAGODENT Oncology and Cardiology Hospital, the members of 'Amazons' Club (Warsaw
- Center, Warsaw - Targówek, Warsaw - Bemowo, Warsaw - Praga, Warsaw - Ochota). The control group $(n=74)$ included women aged over 50 with no history of breast cancer. They were the members of the Cultural Center in Piaseczno, the patients of FizjoSystem Rehabilitation Center, the patients of Estetica-med Rehabilitation Center and their female acquaintances and relatives. They were informed about the study with banners and leaflets. Information about the possibility of participation in the study was also available from attending physicians. All the participants were postmenopausal on the day of interview.

Diagnostic poll method with the authors' questionnaire was used in the study. The questions referred to dietary habits, physical activity, breastfeeding and demographic data. The sizes of portions declared and the frequency of consuming various products were calculated into average consumption expressed in grams, non-alcoholic beverage consumption was specified in milliliters and alcoholic drinks were calculated into grams of ethanol included.

All the participants were weighed without clothes with electronic scales set to an accuracy of $0.1 \mathrm{~kg}$. The obtained results were used to calculate BMI (body weight $(\mathrm{kg}) /$ height $\left.(\mathrm{cm})^{\wedge} 2\right)$. BMI ranges referring to normal and deficient body weight and also being overweight or obese were adopted according to $\mathrm{WHO}$ recommendations [29]. Study participants were also asked about body weight over individual decades of life. This facilitated an estimation of BMI value over different age ranges.

The assessment of compliance with WCRF/AICR recommendations was conducted with reference to 8 of them: body weight, physical activity, consumption of foods and drinks promoting body weight gain, consumption of foods of plant origin, processed and red meat, alcoholic drinks, table salt and breast-feeding. Depending on the grade of adherence to the recommendations the following scores were assigned: recommendation completely met - 1 point, recommendation partially met -0.5 point, recommendation not met -0 points. A detailed method of scoring was presented in Table 2 . The scoring method was modeled on those implemented by other authors $[24,26]$. 
Statistical significance of intergroup differences was assessed with the Mann-Whitney $U$ test for continuous variables and Pearson's chi-squared test for categorical variables. The level of statistical significance was assumed at $p<0.05$.

The study was approved by the Bioethics Board of the Medical University of Warsaw. The participants were informed about the aim and method of conducting the study which they confirmed by signing a written consent for the participation.

\section{RESULTS}

Table 1 shows detailed characteristics of the groups. Women from group II were significantly older and significantly more frequently had had menopause prior to developing breast cancer than women from group I. They were also less professionally active than control group women.

Table 1. General description of study groups and the control group

\begin{tabular}{|c|c|c|c|c|c|}
\hline \multirow[b]{2}{*}{ Variable } & \multicolumn{4}{|c|}{ Group } & \multirow[b]{2}{*}{$\mathrm{p}$ (I vs II) } \\
\hline & $\begin{array}{c}\text { Controls } \\
n=74\end{array}$ & $\begin{array}{c}\mathrm{I} \\
\mathrm{n}=82\end{array}$ & $\begin{array}{c}\mathrm{II} \\
\mathrm{n}=26\end{array}$ & $\begin{array}{c}\mathrm{I}+\mathrm{II} \\
\mathrm{n}=108\end{array}$ & \\
\hline $\begin{array}{l}\text { Age (years) } \\
\mathrm{x} \pm \mathrm{SD} \\
\text { median }\end{array}$ & $\begin{array}{c}65.7 \pm 6.54 \\
66.0 \\
\end{array}$ & $\begin{array}{c}67.0 \pm 7.08 \\
66.0 \\
\end{array}$ & $\begin{array}{c}71.1 \pm 8.05^{* * *} \\
72.5 \\
\end{array}$ & $\begin{array}{c}68.0 \pm 7.50^{*} \\
67.0 \\
\end{array}$ & $<0.01$ \\
\hline $\begin{array}{l}\text { Menopause prior to developing the first } \\
\text { neoplasm } \\
\text { No }(\%) \\
\text { Yes }(\%)\end{array}$ & 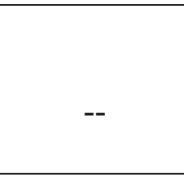 & $\begin{array}{l}59.76 \\
40.24 \\
\end{array}$ & $\begin{array}{l}34.62 \\
65.38 \\
\end{array}$ & $\begin{array}{l}53.70 \\
46.30 \\
\end{array}$ & $<0.05$ \\
\hline $\begin{array}{l}\text { Number of years after diagnosing the first } \\
\text { neoplasm } \\
\mathrm{x} \pm \mathrm{SD} \\
\text { median }\end{array}$ & -- & $\begin{array}{c}14.6 \pm 6.92 \\
13.5 \\
\end{array}$ & $\begin{array}{c}16.8 \pm 7.18 \\
17.0 \\
\end{array}$ & \begin{tabular}{|c|}
$15.2 \pm 7.02$ \\
15.0 \\
\end{tabular} & ns \\
\hline $\begin{array}{l}\text { Number of years after diagnosing the } \\
\text { second neoplasm } \\
\mathrm{x} \pm \mathrm{SD} \\
\text { median }\end{array}$ & -- & 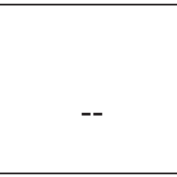 & $\begin{array}{c}10.5 \pm 8.22 \\
10.5 \\
\end{array}$ & 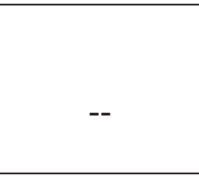 & -- \\
\hline $\begin{array}{l}\text { Age at diagnosis of the first neoplasm } \\
\text { (years) } \\
\mathrm{x} \pm \mathrm{SD} \\
\text { median }\end{array}$ & -- & $\begin{array}{c}52.3 \pm 8.19 \\
51.0 \\
\end{array}$ & $\begin{array}{c}54.2 \pm 10.55 \\
56.0 \\
\end{array}$ & \begin{tabular}{|c|}
$52.8 \pm 8.80$ \\
52.0 \\
\end{tabular} & ns \\
\hline $\begin{array}{l}\text { Age at the diagnosis of the second } \\
\text { neoplasm (years) } \\
\mathrm{x} \pm \mathrm{SD} \\
\text { median }\end{array}$ & -- & -- & $\begin{array}{c}60.5 \pm 11.82 \\
60.0 \\
\end{array}$ & -- & -- \\
\hline $\begin{array}{l}\text { Level of education } \\
\text { Higher }(\%) \\
\text { Secondary }(\%) \\
\text { Elementary }(\%) \\
\end{array}$ & $\begin{array}{c}52.70 \\
45.95 \\
1.35 \\
\end{array}$ & $\begin{array}{c}46.34 \\
53.66 \\
0.00 \\
\end{array}$ & $\begin{array}{c}34.62 \\
65.38 \\
0.00 \\
\end{array}$ & $\begin{array}{c}43.52 \\
56.48 \\
0.00 \\
\end{array}$ & ns \\
\hline $\begin{array}{l}\text { Occupational activity } \\
\text { No }(\%) \\
\text { Yes }(\%)\end{array}$ & $\begin{array}{l}67.57 \\
32.43 \\
\end{array}$ & $\begin{array}{l}69.51 \\
30.49 \\
\end{array}$ & $\begin{array}{c}88.46 \\
11.54 *\end{array}$ & $\begin{array}{l}74.07 \\
25.93\end{array}$ & ns \\
\hline $\begin{array}{l}\text { Place of residence } \\
\text { Big city }(\%) \\
\text { Town }(\%) \\
\text { Village }(\%) \\
\end{array}$ & $\begin{array}{c}95.95 \\
2.70 \\
1.35\end{array}$ & $\begin{array}{c}90.24 \\
8.54 \\
1.22 \\
\end{array}$ & $\begin{array}{c}88.46 \\
11.54 \\
0.00\end{array}$ & $\begin{array}{l}89.81 \\
9.26 \\
0.93 \\
\end{array}$ & ns \\
\hline
\end{tabular}

Statistical significance for comparison with the control group: ${ }^{*} \mathrm{p}<0.05,{ }^{* *} \mathrm{p}<0.01,{ }^{* * *} \mathrm{p}<0.001,{ }^{* * * *} \mathrm{p}<0.0001$

The adherence to individual WCRF/AICR recommendations was different in study group and control group women. Study group women were significantly less physically active, fewer of them adhered to the recommendation concerning appropriate consumption of fruit and vegetables and limiting the consumption of red mead, cold cuts and table salt. Additionally, the participants who experienced a recurrence significantly less commonly observed the recommendation regarding the avoidance of sweetened beverages (Table 2). After adding the points it was noted that women from groups I and II adhered to WCRF/AICR recommendations to a significantly lower degree than those in the control group (Table 3). 


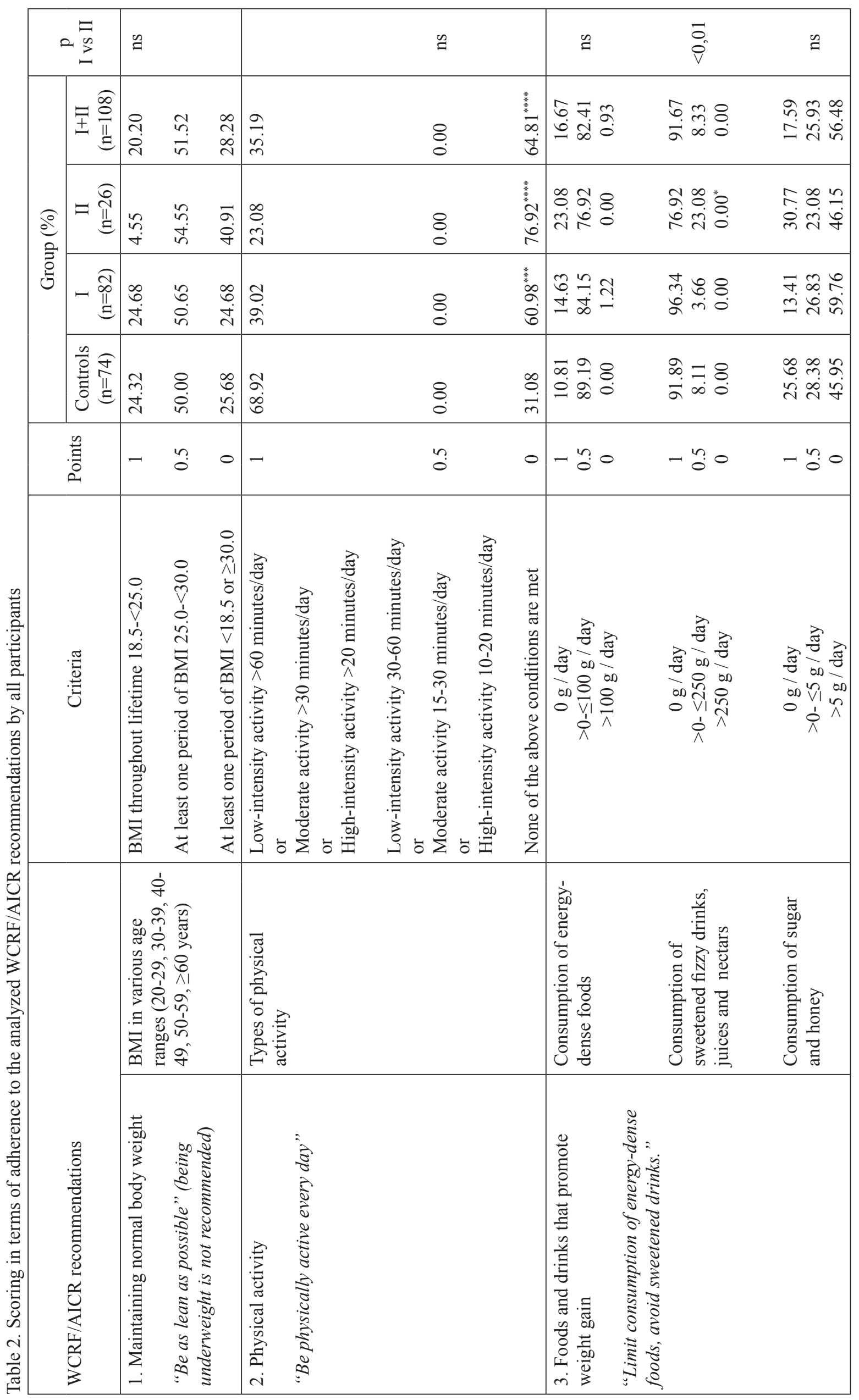




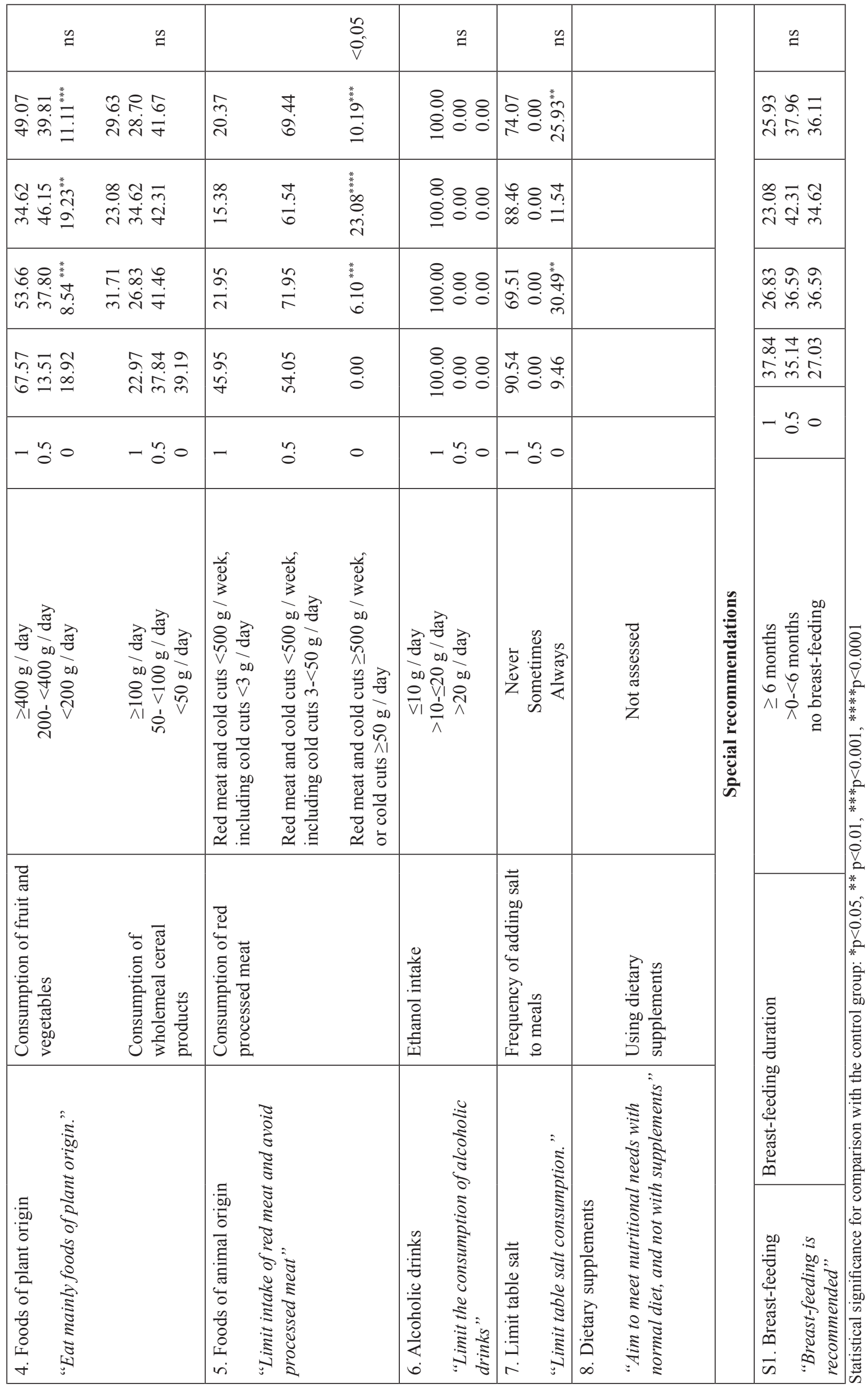


Table 3. Scores assigned for the adherence to the analyzed WCRF/AICR recommendations by all participants

\begin{tabular}{|c|c|c|c|c|c|}
\hline \multirow[b]{2}{*}{ Points in total } & \multicolumn{4}{|c|}{ Group } & \multirow[b]{2}{*}{$\mathrm{p}$ (I vs II) } \\
\hline & $\begin{array}{c}\text { Controls } \\
\mathrm{n}=74\end{array}$ & $\begin{array}{c}I \\
n=82\end{array}$ & $\begin{array}{c}\text { II } \\
n=26\end{array}$ & $\begin{array}{c}\mathrm{I}+\mathrm{II} \\
\mathrm{n}=108\end{array}$ & \\
\hline $\begin{array}{l}\mathrm{x} \pm \mathrm{SD} \\
\text { median }\end{array}$ & $\begin{array}{c}6.4 \pm 1.48 \\
5.5\end{array}$ & $\begin{array}{c}5.6 \pm 1.39^{* * *} \\
5.5\end{array}$ & $\begin{array}{c}5.2 \pm 1.16^{* * *} \\
5.0\end{array}$ & $\begin{array}{c}5.5 \pm 1.34^{* * * * *} \\
5.5\end{array}$ & $\mathrm{~ns}$ \\
\hline
\end{tabular}

Statistical significance for comparison with the control group: ${ }^{*} \mathrm{p}<0.05,{ }^{* *} \mathrm{p}<0.01,{ }^{* * *} \mathrm{p}<0.001,{ }^{* * * *} \mathrm{p}<0.000$

Table 4 presents the adherence to individual WCRF/AICR recommendations by study participants who declared no changes in dietary habits after being diagnosed with breast cancer. In this case significant differences between the study and control groups were only observed as regards the participants with a recurrence. They were less physically active than women oncologically healthy, fewer of them adhered to the recommendation concerning reduced consumption of sweet beverages, red meat and cold cuts and also an appropriate duration of breast-feeding. However, after adding the points it was shown that women from groups with and without the recurrence adhered to WCRF/AICR recommendations to a significantly lower degree than those in the control group (Table 5).

\section{DISCUSSION}

The present study confirmed that women with a history of cancer only partially observed the recommendations regarding lifestyle developed by WCRF/AICR. It is consistent with results published by other authors. Research conducted over the past few years has shown that patients with a history of an oncological disorder are not consistent in adhering to such health-related recommendations. Over $50 \%$ of such patients were overweight, over $50 \%$ do not adhere to recommendations concerning physical activity and only approx. 20\% observe the recommendation regarding fruit and vegetable consumption. Additionally, as many as $90 \%$ of individuals with a history of an oncological disease do not adhere to the recommendation concerning alcohol consumption $[3,4,15]$.

The relationship between the adherence to recommendations and the development of breast cancer was analysed in a prospective cohort study which included over 30 thousand women without a history of breast cancer aged 50-76 years. A total of 899 breast cancer cases were confirmed after 6.7 years. The comparison of dietary habits of study participants and AICR/WCRF recommendations demonstrated that the adherence to at least five recommendations resulted in the reduction of the risk of the development of breast cancer at the level of as much as $60 \%$. Maintaining normal body weight and the consumption of foods of plant origin appeared to be particularly important in the context of risk reduction, while alcohol consumption appeared to be increasing the risk [9].
Similarly, a Canadian study including over 49 thousand women with breast cancer also confirmed a relationship between the adherence to AICR/WCRF recommendations and the reduction of the risk of breast cancer. Adherence to six or more recommendations resulted in the reduction of the risk by $21 \%$. Adherence to each subsequent recommendation lowered the risk by another $5 \%$. The strongest influence on the risk of breast cancer occurrence was noted for recommendations concerning meat, energy-dense food and wholemeal cereal products [6].

A prospective cohort EPIC study showed that higher adherence to WCRF/AICR recommendations was associated with a lower risk of developing various neoplasms, such as cancer of the colon, stomach, breast, endometrium, lung, kidney and esophagus. The risk of developing a cancer in individuals with the highest score ( $\geq 5$ points in men and $\geq 6$ points in women) was lower by $18 \%$ than in those with the lowest score $(\leq 2$ points in men and $\leq 3$ points in women) [22].

Low level of adherence to WCRF/AICR recommendations in the present study was comparable with the findings of studies on neoplasms other than breast cancer $[10,12,17,20,26]$. Individuals with a history of neoplastic disease were less adherent to the recommendations concerning nutrition and physical activity than healthy ones. One study showed that lifestyle and body weight were not in line with the recommendations in colon cancer patients. Reducing the consumption of foods of animal origin ( $8 \%$ of respondents) and increasing the ratio of foods of plant origin ( $9 \%$ of respondents) were the least commonly observed recommendations. The recommendation which was the best adhered to was one concerning avoiding dietary supplements ( $75 \%$ of respondents). An improvement of dietary habits introduced after diagnosing a neoplasm was declared by $25 \%$ of respondents [26].

Poor adherence to the recommendations was also notedinadults whohadsufferedfromacute lymphoblastic leukaemia in childhood. None of the participants adhered to all WCRF/AICR recommendations and the average value of BMI in the study group was over 27 , which means being overweight. Only half of the study group declared the consumption of 5 portions of fruit and vegetables daily. The levels of table salt and sugar consumption considerably exceeded the criteria of recommendations [20]. 


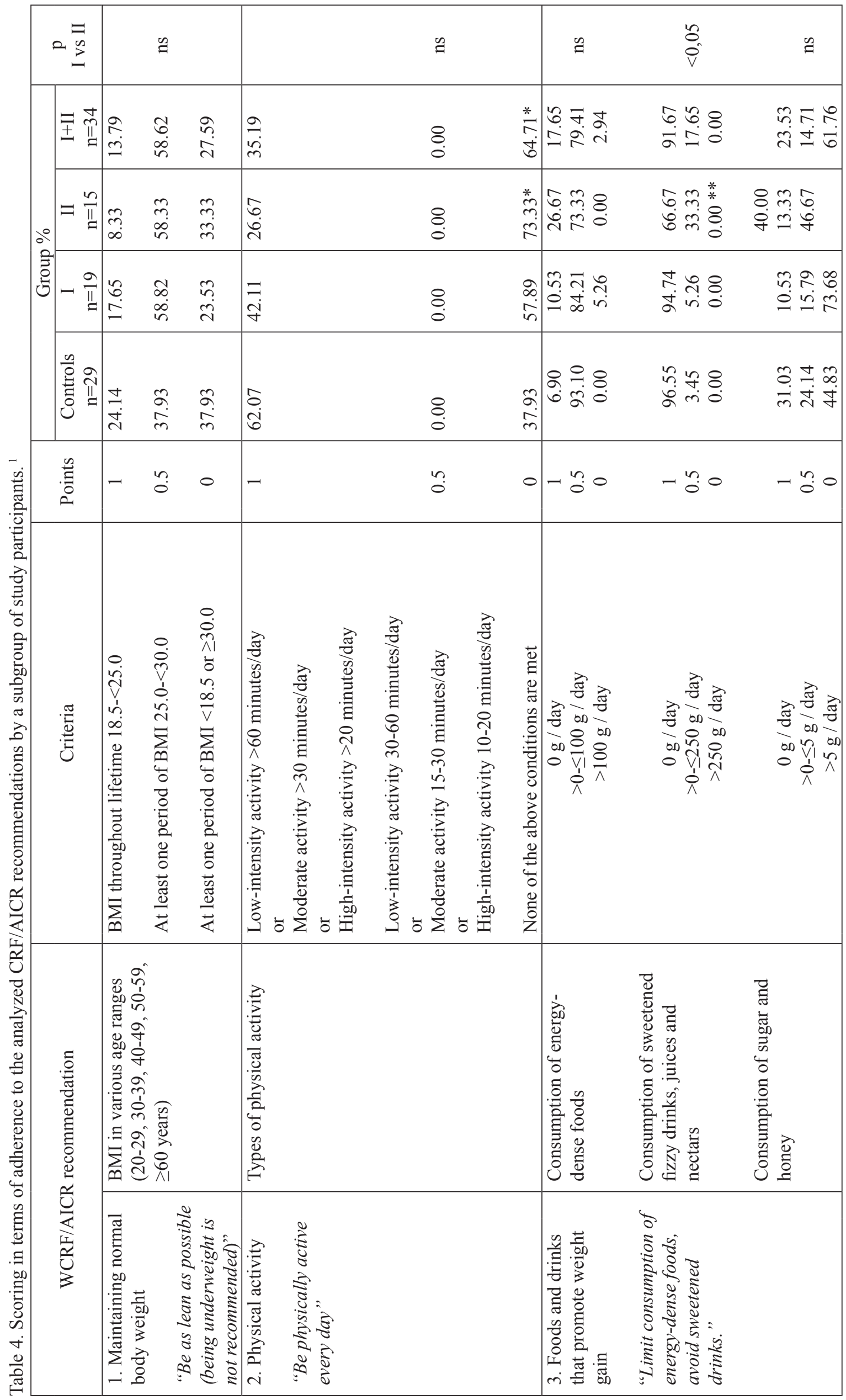




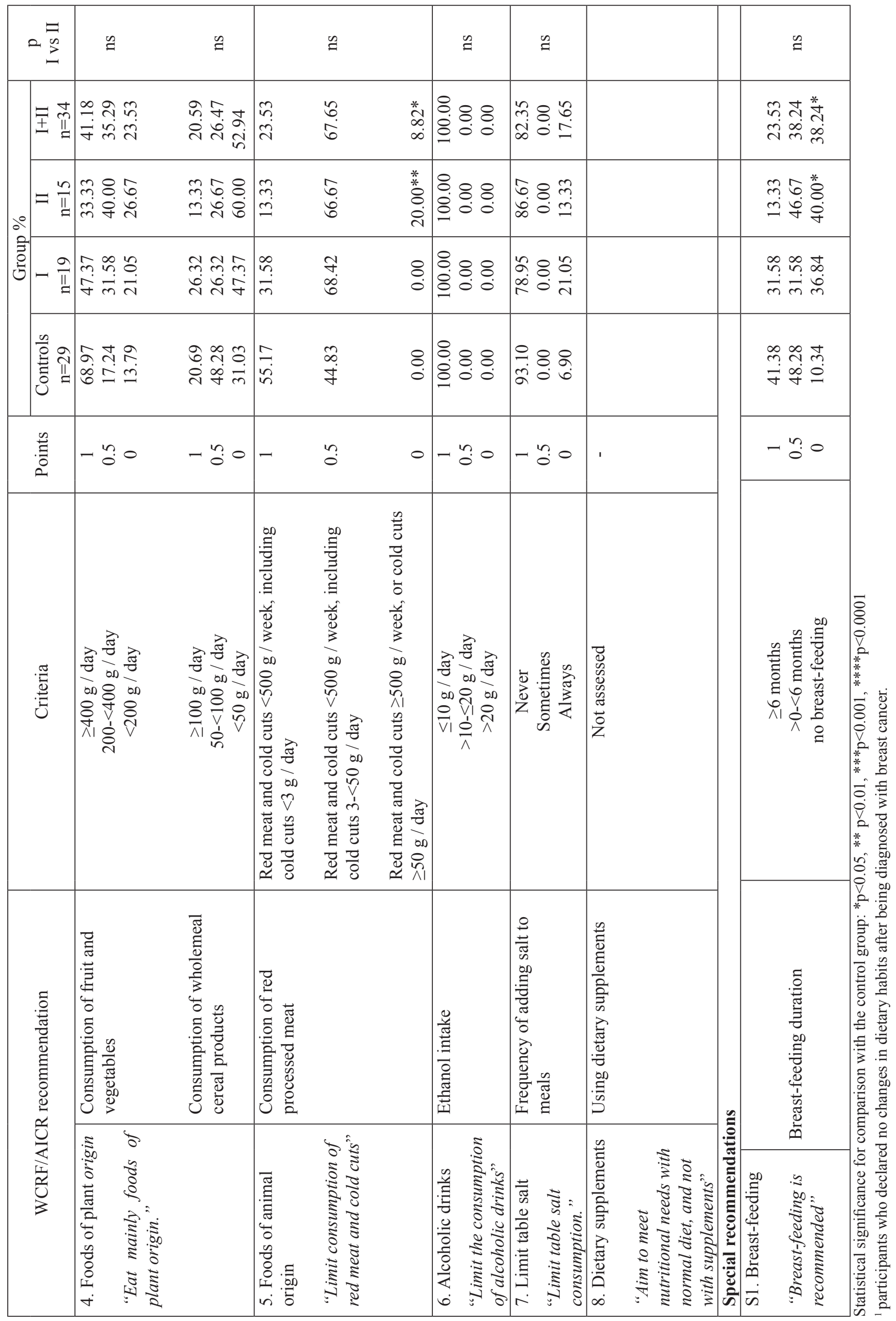


Table 5. Scores assigned for the adherence to analyzed WCRF/AICR recommendations by a subgroup of study participants $^{1 .}$

\begin{tabular}{|l|c|c|c|c|c|}
\hline \multirow{2}{*}{ Points in total } & \multicolumn{4}{|c|}{ Group } & \multirow{2}{*}{$\mathrm{p}$ (I vs II) } \\
\cline { 2 - 5 } & Controls & $\mathrm{n}=29$ & $\mathrm{n}=19$ & $\mathrm{II}$ & $\mathrm{I}+\mathrm{II}$ \\
$\mathrm{yyyyy}$ & $\mathrm{x} \pm \mathrm{SD}$ & $5.5 \pm 1.17^{* *}$ & $5.0 \pm 1.32^{* * *}$ & $5.3 \pm 1.24^{* * * *}$ & \multirow{2}{*}{$\mathrm{ns}$} \\
median & $6.6 \pm 1.38$ & 5.5 & 4.5 & 5.0 & \\
\hline
\end{tabular}

Statistical significance for comparison with the control group: ${ }^{*} \mathrm{p}<0.05, * * \mathrm{p}<0.01,{ }^{* * *} \mathrm{p}<0.001, * * * * \mathrm{p}<0.0001$

${ }^{1}$ participants who declared no changes in dietary habits after being diagnosed with breast cancer.

Similarly, a study including Dutch patients with various types of cancer demonstrated that the lifestyle of only a small group (11\%) was consistent with all assessed recommendations. The majority of participants $(>80 \%)$ adhered only to two or three recommendations. The largest number of individuals adhered to the recommendations concerning physical activity (87.4\%) and alcohol intake (75.4\%) [12].

Similar results were obtained in a prospective cohort study which included over 177 thousand men and women with a history of neoplastic disease. Persons suffering from cancer less commonly observed WCRF/AICR recommendations than individuals free of oncological diseases. Individuals who had had a history of breast or prostate cancer were more willing to adhere to the recommendations than patients with other types of neoplasms [17].

It is worth noting the results of a cohort Iowa Women's Health Study which included over 2 thousand women aged 55-69 with various neoplasms. Women who reported a higher adherence to WCRF/ AICR recommendations were less prone to all-cause death. The risk of death in participants who scored $\leq 4$ points was $33 \%$ higher than in women who scored at least 6 out of 8 points available [4].

Notably, a study including elderly women with a history of oncological disease demonstrated that higher adherence to WCRF/AICR recommendations was associated with better quality of life, both in terms of physical and mental status [10].

The present study showed the lowest adherence to WCRF/AICR recommendations in case of the consumption of fruit and vegetables, red and processed meat and sweetened fizzy drinks. The authors of other studies obtained similar results except for the association concerning sweetened drinks. It is worth noting that an extensive meta-analysis comprising several prospective studies showed a negative relationship between the consumption of fruit and fruit and vegetables (combined) and the risk of developing breast cancer [2]. A study conducted in Szczecin included 257 women with confirmed breast cancer (invasive or in situ). It was demonstrated that the risk of developing breast cancer in women who consumed fruit and vegetables daily or several times a day was considerably lower than in women whose consumption of such products was several times a month or less frequently [13]. Poor adherence to recommendations concerning the consumption of fruit and vegetables was also observed in a case-control study of patients with various types of cancer [12]. Slightly over half of the patients $(54.8 \%)$ adhered to the recommendation concerning the amount of fruit consumed and even fewer (27.4\%) - the recommendation concerning vegetable consumption.

Several mechanisms are responsible for the protective properties of fruit and vegetables. Fruit and vegetables are sources of phytochemicals inducing the activity of detoxifying enzymes which deactivate carcinogens. Antioxidants found in such products reduce oxidative stress and alleviate inflammation [18]. High dietary intake of polyphenols reduced process of inflammation in patients with breast cancer [23]. Moreover, fruit and vegetables are rich in fiber, which, due to its potential to bind estrogens, may be favorable in diminishing the risk of developing breast cancer [1]. The influence of fruit and vegetable consumption on the reduction of the risk of being overweight and obese, which constitute the risk factor of breast cancer is an additional protective mechanism [25]. Moreover, avoiding overweight and obesity seems to reduce the risk of breast cancer recurrence [11].

The association between the consumption of red and processed meat with the development of breast cancer was confirmed in a meta-analysis comprising 14 prospective studies. The comparison of the highest and lowest categories of consumption showed that the risk of breast cancer was higher by $10 \%$ for red meat and by $8 \%$ higher for processed meat [15]. The relationship between the consumption of processed meat and the risk of developing breast cancer was also confirmed by Spanish researchers. In the conclusions section of their case-control study including over a thousand women with breast cancer they stated that the risk of developing breast cancer may be limited by reducing the consumption of well-done or stewed red meat, fried and bread-coated white meat and cured meat [5]. Similar results were also obtained in another case-control study which included women with a diagnosis of breast cancer. It was demonstrated that the consumption of processed meat only once or twice a week was associated with a 2.7-fold higher probability of the development of breast cancer in women who reported no consumption of processed meat [16]. 
Notably, the results of a cohort study including over 1500 women with breast cancer confirmed that a high consumption of grilled and smoked meat may increase overall mortality. The comparison of high and low consumption of grilled meat was associated with the overall risk of death higher by $23 \%$. In case of smoked meat the risk increased by $17 \%$ in case of all-cause mortality and by $23 \%$ in case of breast cancer [19].

The consumption of red and processed meat may be associated with the risk of neoplasms other than breast cancer. According to the World Health Organization, the consumption of red meat is a possible and the consumption of processed meat is an evident risk factor of colon cancer [30]. It was confirmed by the results of a cohort study including patients with colon cancer and showed the lowest adherence to WCRF/ AICR recommendations regarding the consumption of red and processed meat and foods of plant origin [4].

The mechanism of carcinogenic properties of meat is still researched. It is assumed that substances produced during the conversion of heme iron may damage cell DNA. Thermal meat processing increases its harmful effect because of producing polycyclic aromatic hydrocarbons and heterocyclic aromatic amines. Nitrates and nitrites added during the production of cold cuts may react with meat protein and form nitrosamines [7].

Presumably, appropriate physical activity may constitute a fundamental intervention in diminishing the number of cases of breast cancer and deaths among individuals with a history of breast cancer. The present study group women were also less physically active than the controls, which is consistent with results published by other authors. A meta-analysis of 31 prospective studies revealed that regular physical activity may have a significant influence on the reduction of the risk of developing breast cancer [14]. Another extensive meta-analysis also confirmed the protective aspects of physical activity in reducing the number of recurrences and deaths due to breast cancer [4].

The present study has a few limitations. One of them is the case-control character of the study which impedes the assessment of cause and effect associations. The risk of errors resulting from unreliable memory of the participants may also contribute to the list of problems. The absence of some data regarding lifestyle in the past, especially as regards physical activity also obstructed the present evaluation.

\section{CONCLUSIONS}

1. The results of the study confirmed the benefits of complying with WCRF/AICR recommendations in the prevention of breast cancer.

2. Physical activity and consumption of foods of plant origin appears to have a positive influence on the risk of developing breast cancer.
3. The consumption of processed and red meat probably increases the risk of breast cancer.

\section{Conflict of interest}

The authors declare no conflict of interest.

\section{REFERENCES}

1. Aune D., Chan D.S.M., Greenwood D.C., Vieira A.R., Rosenblatt D.N., Vieira R., Norat, T.: Dietary fiber and breast cancer risk: a systematic review and metaanalysis of prospective studies. Annals of oncology. 2012;23 Suppl 6:1394-1402.

2. Aune D., Chan D.S., Viera A.R., Rosenblatt D.A., Vieira R., Greenwood D.C., Norat T.: Fruits, vegetables and breast cancer risk: a systematic review and metaanalysis of prospective studies. Breast Cancer Res Treat. 2012;134 Suppl 2:479-93.

3. Bellizzi K.M., Rowland J.H., Jeffery D.D., McNeel $T$.: Health behaviors of cancer survivors: examining opportunities for cancer control intervention. J Clin Oncol. 2005; doi: 10.1200/jco.2005.02.2343.

4. Blanchard C.M., Courneya K.S., Stein K.: Cancer survivors' adherence to lifestyle behavior recommendations and associations with health-related quality of life: Results from the American Cancer Society's SCS-II. J Clin Oncol. 2008; doi:10.1200/ JCO.2007.14.6217.

5. Boldo E., Castelló A., Aragonés N., Amiano P., PérezGómez B., Castaño-Vinyals G,Martin V., Guevara M., Urtiga C., Dierssen-Sotos T., Fernández-Tardón G., Moreno V., Solans M., Peiró R., Capelo R., GómezAcebo I., Castilla J., Molina A.J., Castells X., Altzibar J.M., Lope V., Kogevinas M., Romieu I., Pollán M.: Meat intake, methods and degrees of cooking and breast cancer risk in the MCC-Spain study. Maturitas. 2018;110:62-70.

6. Catsburg C., Miller A.B., Rohan T.E.: Adherence to cancer prevention guidelines and risk of breast cancer. Int J Cancer. 2014;135 Suppl 10:2444-52.

7. Demeyer D., Mertens B., De Smet S., Ulens M.: Mechanisms Linking Colorectal Cancer to the Consumption of (Processed) Red Meat: A Review. Crit Rev Food Sci Nutr. 2016 9;56 Suppl 16:2747-66. doi: 10.1080/10408398.2013.873886.

8. Guo J., Wei W., Zhan L.: Red and processed meat intake and risk of breast cancer: a meta-analysis of prospective studies. Breast Cancer Res Treat. 2015;151 Suppl 1:191-198.

9. Hastert T.A., Beresford S.A., Patterson R.E., Kristal A.R., White E.: Adherence to WCRF/AICR cancer prevention recommendations and risk of post-menopausal breast cancer. Cancer Epidemiol Biomarkers Prev. 2013;22 Suppl 9:1498-508.

10. Inoue-Choi M., Lazovich D., Prizment A.E., Robien $K$.: Adherence to the World Cancer Research Fund/ American Institute for Cancer Research recommendations for cancer prevention is associated with better health-related quality of life among elderly female cancer survivors. J Clin Oncol. 2013; 31:1758-66. 
11. Kałędkiewicz E., Szostak-Węgierek D.: Dietary practices and nutritional status in survivors of breast cancer. Rocz Panstw Zakl Hig 2018, 69(2): 175:182.

12. Kanera I.M., Bolman C.A.W., Mesters I., Willems R.A., Beaulen A.A.J.M., Lechner L.: Prevalence and correlates of healthy lifestyle behaviors among early cancer survivors. BMC Cancer. 2016;16:1-18.

13. Kruk J.: Jedzenie owoców i warzyw a ryzyko raka piersi. Współcz Onkol. 2008;10 Suppl 5:224-230.

14. Lahart I.M., Metsios G.S., Nevill A.M., Carmichael $A R$.: Physical activity, risk of death and recurrence in breast cancer survivors: A systematic review and metaanalysis of epidemiological studies. Acta Oncologica. 2015;54 Suppl 5:635-654.

15. LeMasters T.J., Madhavan S.S., Sambamoorthi U., Kurian S.: Health behaviors among breast, prostate, and colorectal cancer survivors: a US populationbased case-control study, with comparisons by cancer type and gender. J Cancer Surviv. 2014; doi: 10.1007/ s11764-014-0347-5.

16. Mourouti N., Kontogianni M.D., Papavagelis C., Plytzanopoulou P., Vassilakou T., Psaltopoulou T., Malamos N., Linos A., Panagiotakos D.B.: Meat consumption and breast cancer: a case-control study in women. Meat Sci. 2015;100:195-201.

17. Ollberding N.J., Maskarinec G., Wilkens L.R., Henderson B.E., Kolonel LN.: Comparison of modifiable health behaviours between persons with and without cancer: the multiethnic cohort. Public Health Nutr. 2011;14:1796-1804.

18. Pantavos A., Ruiter R., Feskens E.F., de Keyser C.E., Hofman A., Stricker B.H., Franco O.H., Kiefte-de Jong J.C.: Total dietary antioxidant capacity, individual antioxidant intake and breast cancer risk: The Rotterdam study. Int J Cancer. 2015;136 Suppl 9:2178-2186.

19. Parada H., Steck S.E., Bradshaw P.T., Engel L.S., Conway K., Teitelbaum S.L., Neugut A.I., Santella R.M., Gammon M.D.: Grilled, barbecued, and smoked meat intake and survival following breast cancer. JNCI. 2017;109(6) doi: 10.1093/jnci/djw299.

20. Robien K., Ness K.K., Klesges L.M., Baker K.S., Gurney $J . G$. Poor adherence to dietary guidelines among adult survivors of childhood acute lymphoblastic leukemia. J. Pediatr. Hematol. Oncol. 2008;30:815-822.

21. Rock C.L., Doyle C., Demark-Wahnefried W., Meyerhardt J., Courneya K.S., Schwartz A.L., Bandera E.V., Hamilton K.K., Grant B., McCullough M., Byers T., Gansler T.: Nutrition and physical activity guidelines for cancer survivors. CA Cancer J Clin. 2012;62 Suppl 4:243-74.

22. Romaguera D., Vergnaud A.C., Peeters P.H., van Gils C.H., Chan D.S., Ferrari P., Romieu I., Jenab M., Slimani N., Clavel-Chapelon F., Fagherazzi G., Perquier F., Kaaks R., Teucher B., Boeing H., von Rüsten A., Tjønneland A., Olsen A., Dahm C.C., Overvad K., Quirós J.R., Gonzalez C.A., Sánchez M.J., Navarro C., Barricarte A., Dorronsoro M., Khaw
K.T., Wareham N.J., Crowe F.L., Key T.J., Trichopoulou A., Lagiou P., Bamia C., Masala G., Vineis P., Tumino R., Sieri S., Panico S., May A.M., Bueno-de-Mesquita H.B., Büchner F.L., Wirfält E., Manjer J., Johansson I., Hallmans G., Skeie G., Benjaminsen Borch K., Parr C.L., Riboli E., Norat T.: Is concordance with World Cancer Research Fund/American Institute for Cancer Research guidelines for cancer prevention related to subsequent risk of cancer? Results from the EPIC study. Am J Clin Nutr. 2012;96;1 Suppl 1:150-163.

23. Sut A., Pytel M., Zadrożny M., Golański J., Rozalski M.: Polyphenol-rich diet is associated with decreased level of inflammatory biomarkers in breast cancer patients. Rocz Panstw Zakl Hig 2019; 70(2):177-184.

24. Vergnaud A.C., Romaguera D., Peeters P.H., van Gils C.H., Chan D.S., Romieu I., Freisling H., Ferrari P., Clavel-Chapelon F., Fagherazzi G., Dartois L., Li K., Tikk K., Bergmann M.M., Boeing H., Tjønneland A., Olsen A., Overvad K., Dahm C.C., Redondo M.L., Agudo A., Sánchez M.J., Amiano P., Chirlaque M.D., Ardanaz E., Khaw K.T., Wareham N.J., Crowe F., Trichopoulou A., Orfanos P., Trichopoulos D., Masala G., Sieri S., Tumino R., Vineis P., Panico S., Bueno-de-Mesquita H.B., Ros M.M., May A., Wirfält E., Sonestedt E., Johansson I., Hallmans G., Lund E., Weiderpass E., Parr C.L., Riboli E., Norat T.: Adherence to the WCRF/AICR guidelines and risk of death in Europe: results from the European Prospective Investigation into Nutrition and Cancer cohort study. Am J Clin Nutr. 2013;97:1107-20.

25. Vucenik I., Stains J.P.: Obesity and cancer risk: evidence, mechanisms, and recommendations. Annals of the New York Academy of Sciences. 2012;1271 Suppl 1:37-43.

26. Winkels R.M. van Lee L., Beijer S., Bours M.J., van Duijnhoven F.J.B., Geelen A., Hoedjes M., Mols F., de Vries J., Weijenberg M.P., Kampman E.: Adherence to the WCRF/AICR lifestyle recommendations in colorectal cancer survivors: results of the Profiles registry. Cancer Med. 2016;5 Suppl 9:2587-95.

27. Wojciechowska U., Olasek P., Czauderna K., Didkowska $J$.: Nowotwory złośliwe w Polsce w 2014 roku. Krajowy Rejestr Nowotworów, Centrum Onkologii - Instytut im. Marii Skłodowskiej-Curie. Warszawa, 2016. http:// onkologia.org.pl/wp-content/uploads/Nowotwory2014. pdf

28. World Cancer Research Fund/American Institute for Cancer Research. Food, nutrition, physical activity, and the prevention of cancer: a global perspective. Washington DC, 2007.

29. World Health Organization. BMI Classification. Available http://apps.who.int/bmi/index.jsp?introPage=intro_3.html (Accessed 10.05.2019)

30. World Health Organization. http://www.who.int/features/qa/cancer-red-meat/en/ Accessed 03.052019.

Received: 05.06.2019

Accepted: 31.07 .2019

This article is available in Open Access model and licensed under a Creative Commons Attribution-Non Commercial 3.0.Poland License (CC-BY-NC) available at: http://creativecommons.org/licenses/by-nc/3.0/pl/deed.en 